\title{
肺野部小型肺癌に対するThinーSection CTの有用性
}

\author{
Thin-Section CT of Peripheral Small Lung Cancer
}

栗山啓子 ${ }^{1} \cdot$ 梶田明義 $^{1} \cdot$ 藤野保定 $^{1} \cdot$ 児玉 憲 ${ }^{2} \cdot$ 土井 修 2

宝来 威 $^{3} \cdot$ 松田 実 $^{3} \cdot$ 建石龍平 $^{4} \cdot$ 池添潤平 $^{5} \cdot$ 森本静夫 $^{5}$

\begin{abstract}
要旨：術前確定診断の困難であった肺野部小型肺癌 7 症例に対し, thin-section CT (1.5mm) を施行しその有効性を検討した。

従来のX線学的手法に比して, 濃度・空間分解能が良く, 腫瘤影内部の小空洞や辺縁の 性状, 胸膜陥入像や周囲の血管・気管支の集束性変化の描出に優れていた，拡大スケー ルにより腫瘤影内部の濃度差, 腫瘍内気管支の描出が可能で, 切除肺の病理像と良く対 応し肺野部小型肺癌の画像診断として極めて有用であった。
\end{abstract}

〔肺癌 $27(6): 671 \sim 678,1987$ 〕

Key words : Lung cancer, Computed tomography, Diagnosis.

\section{はじめに}

早期肺癌は X 線診断と喀痰細胞診を主体とし た集団検診の普及に伴い増加しつつある11. 肺 癌の確定診断は最終的には病理学的診断法でな されるが, 肺野部小型肺癌では腫瘍細胞の密度 が低く含気性の構築を残しているために陰影が 淡くてX線テレビで可視できない場合があり， 経気管支鏡的擦過細胞診や経皮的肺針生検で術 前に確定診断をつけることが困難な症例に遭遇 する2).このような症例に対しては, 画像診断で 良・悪性の鑑別を行い肺癌が強く疑われる場合 は開胸生検を考慮する必要がある.

従来より肺癌の画像診断は胸部単純写真, $\mathrm{X}$ 線断層。写真, ゼロトモグラム, 気管支造影, 肺動 脈・気管支動脈造影および核医学検査により行

1. 大阪府立成人病センタ一放射線診断科

$\begin{array}{lll}2 . & \text { 同 } & \text { 外科 } \\ 3 . & \text { 同 } & \text { 内科 } \\ 4 . & \text { 同 } & \text { 病理 }\end{array}$

5. 大阪大学医学部放射線科
われてきたが, 最近では非侵襲的で濃度・空間 分解能が良いコンピュータ一断層 $(\mathrm{CT})$ 検查が 普及してきている3),4).われわれは術前確定診断 が困難であった肺野部小型肺癌に対しスライス 厚1.5mmのthin-section CTを用いて肺野腫瘤 影の微細構造の描出を試み, その診断能を胸部 単純写真, $\mathrm{X}$ 線断層写真およびルーチンCT (ス ライス厚 $10 \mathrm{~mm})$ と比較検討した. またthin-section CT所見の解析のためにスキャン面と対応 させて水平にスライスした摘出肺の病理像との 対比検討を行った。

\section{対象および方法}

1986年 1 月から 9 月までの期間に大阪府立成 人病センタ一放射線診断科でCT検査を施行し, 手術により組織診断がなされている肺野部小型 肺癌の 7 症例に対し検討を加えた。

性別は男性 6 名, 女性 1 名で年齡は45歳から 72 歳に分布し, 平均 61 歳であった. 腫瘍の発生 部位は全例右側で $\mathrm{S}_{2}: 3, \mathrm{~S}_{3}: 2, \mathrm{~S}_{4}: 1, \mathrm{~S}_{6}$ : 
Table 1. 7 cases of small lung cancer.

\begin{tabular}{|c|c|c|c|}
\hline Case/age/sex & $\begin{array}{l}\text { Chest radiograph } \\
\text { and tomogram }\end{array}$ & CT Findings & $\begin{array}{l}\text { Pathological } \\
\text { findings/Size }\end{array}$ \\
\hline $1 / 66 / \mathrm{M}$ & $\begin{array}{l}\text { Questionable small } \\
\text { irregular nodule in } \\
\mathrm{RS}_{2}\end{array}$ & $\begin{array}{l}\text { An irregularly lobulated } \\
\text { nodule with some spiculation } \\
\text { extending to pleural surface }\end{array}$ & $\begin{array}{l}\text { * Papillary } \\
\text { adenocarcinoma } \\
\text { 8x 8mm }\end{array}$ \\
\hline $2 / 45 / F$ & $\begin{array}{l}\text { An ill-defined } \\
\text { solitary nodule in } \\
\mathrm{RS}_{3}\end{array}$ & $\begin{array}{l}\text { A lobulated nodule with } \\
\text { uneven density and airbroncho- } \\
\text { gram }\end{array}$ & $\begin{array}{l}\text { Papillary } \\
\text { adenocarcinoma } \\
15 \times 14 \mathrm{~mm}\end{array}$ \\
\hline $3 / 70 / \mathrm{M}$ & $\begin{array}{l}\text { A lobulated small } \\
\text { nodule in } \mathrm{RS}_{3}\end{array}$ & $\begin{array}{l}\text { A irregularly lobulated } \\
\text { nodule with some spiculation } \\
\text { and vascular convergence }\end{array}$ & $\begin{array}{l}\text { * Papillary } \\
\text { adenocarcinoma } \\
\text { 16x } 9 \mathrm{~mm}\end{array}$ \\
\hline $4 / 72 / \mathrm{M}$ & $\begin{array}{l}\text { A lobulated nodule } \\
\text { in } \mathrm{RS}_{4}\end{array}$ & $\begin{array}{l}\text { A lobulated nodule with } \\
\text { severe vascular convergence }\end{array}$ & $\begin{array}{l}\text { Papillary } \\
\text { adenocarcinoma } \\
19 \times 12 \mathrm{~mm}\end{array}$ \\
\hline $5 / 45 / \mathrm{M}$ & $\begin{array}{l}\text { A small nodule with } \\
\text { uneven density in } \\
\mathrm{RS}_{6}\end{array}$ & $\begin{array}{l}\text { A slightly lobulated nodule } \\
\text { with multiple small cavities }\end{array}$ & $\begin{array}{l}\text { Papillary } \\
\text { adenocarcinoma } \\
19 \times 19 \mathrm{~mm}\end{array}$ \\
\hline 6/63/M & $\begin{array}{l}\text { An ill-defined } \\
\text { solitary nodule in } \\
\mathrm{RS}_{2}\end{array}$ & $\begin{array}{l}\text { An irregularly lobulated nodule } \\
\text { extending to pleural surface }\end{array}$ & $\begin{array}{l}\text { Squamous-cell } \\
\text { carcinoma } \\
19 \times 12 \mathrm{~mm}\end{array}$ \\
\hline $7 / 63 / \mathrm{M}$ & $\begin{array}{l}\text { A well demarcated } \\
\text { solitary nodule in } \\
\mathrm{RS}_{2}\end{array}$ & $\begin{array}{l}\text { A well demarcated, slightly } \\
\text { lobulated nodule }\end{array}$ & $\begin{array}{l}\text { Large-cell } \\
\text { carcinoma } \\
19 \times 7 \mathrm{~mm}\end{array}$ \\
\hline
\end{tabular}

Abbreviations: $\mathrm{RS}_{2}$, right posterior segment ; $\mathrm{RS}_{3}$,right anterior segment; $\mathrm{RS}_{4}$, right lateral segment; $\mathrm{RS}_{6}$, right superior segment. $\quad *$ : Secondary lesion in double primary lung cancers.

1 の順で右上葉に多かった。摘出標本における 腫瘍最大径の最も小さいものは， $8 \mathrm{~mm} ゙$ あっっ た. 病理組織は乳頭腺癌 5 例, 扁平上皮癌 1 例, 大細胞癌 (II 型肺胞上皮癌) 1 例であった (Table 1).

使用したCT装置はGE社製CT/T9800でスキ ヤンはすべて最大吸気の状態で行った，全肺に スライス厚 $10 \mathrm{~mm}$ 連続スキャンを施行したの ちに腫瘤影の位置決めを行い，中心部を含みス ライス厚 $1.5 \mathrm{~mm}$ ，スライス幅 $3 \mathrm{~mm}$ ，スキャン 時間 2 秒, FOV13cm, Matrix 512にて高分解能 CT像を得，腫瘤や血管·気管支の辺縁を鮮明に するBone detail algorithmにて画像処理を行 った，拡大スケールを用いた肺野条件 (window レベル；-600H，window幅；1500H) と腫瘤影 内の小空洞, 石灰化や脂肪を観察するための縦 隔条件 (windowレベル；0-150H，window幅；
Table 2. Comparative study between modalities on early lung cancer.

\begin{tabular}{lcccc}
\hline Findings & \multicolumn{2}{c}{$\begin{array}{c}\text { Plain Conv. } \\
\text { Chest Tomo. }\end{array}$} & CT(10mm) & $\begin{array}{l}\text { Thin-sec- } \\
\text { tion CT }\end{array}$ \\
\hline Notch & 1 & 6 & 2 & 7 \\
Spiculation & 2 & 6 & 2 & 6 \\
Small cavity & 0 & 0 & 1 & 4 \\
Heterogeneous density & 1 & 1 & 2 & 2 \\
Pleural retraction & 1 & 2 & 2 & 5 \\
$\begin{array}{l}\text { Convergence of } \\
\text { peripheral bronchi and vessels }\end{array}$ & 1 & 4 & 5 & 7 \\
& & & & \\
\hline
\end{tabular}

300-500H)により撮像を行った。全例に石灰化 や脂肪, 散布巣は認めなかった。

病変の描出能を比較検討するために, 各症例 ごとに悪性を示唆する形態学的特徵 (辺縁の凹 凸, 棘状突起, 胸膜の陥入, 周囲血管影の集束) を胸部単純写真, X 線断層写真, ルーチン CT ( ス ライス厚 $10 \mathrm{~mm})$, thin-section CT $(1.5 \mathrm{~mm})$ に 
Fig. 1. A 72 year-old man (Case 4) with a history of laryngeal cancer and an adenocarcinoma in the right middle lobe. (A) Localized view of the right lower lung from posteroanterior radiograph shows an ill-defined shadow of increased density with pleural indentation (arrow). (B) Thin-section CT demonstrates lobulated nodule with convergence of peripheral vessels. (C) Correlating pathologic specimen shows it to be poorly-differentiated papillary adenocarcinoma with central cicatrization and necrosis (white arrow). In the 11-2 o'clock sector, poorly defined advancing margins contrast sharply with lobulated well circumscribed margins of remainder of the periphery. Neighboring vessels (arrows) show confluence towards the lesion by central scarring.

A
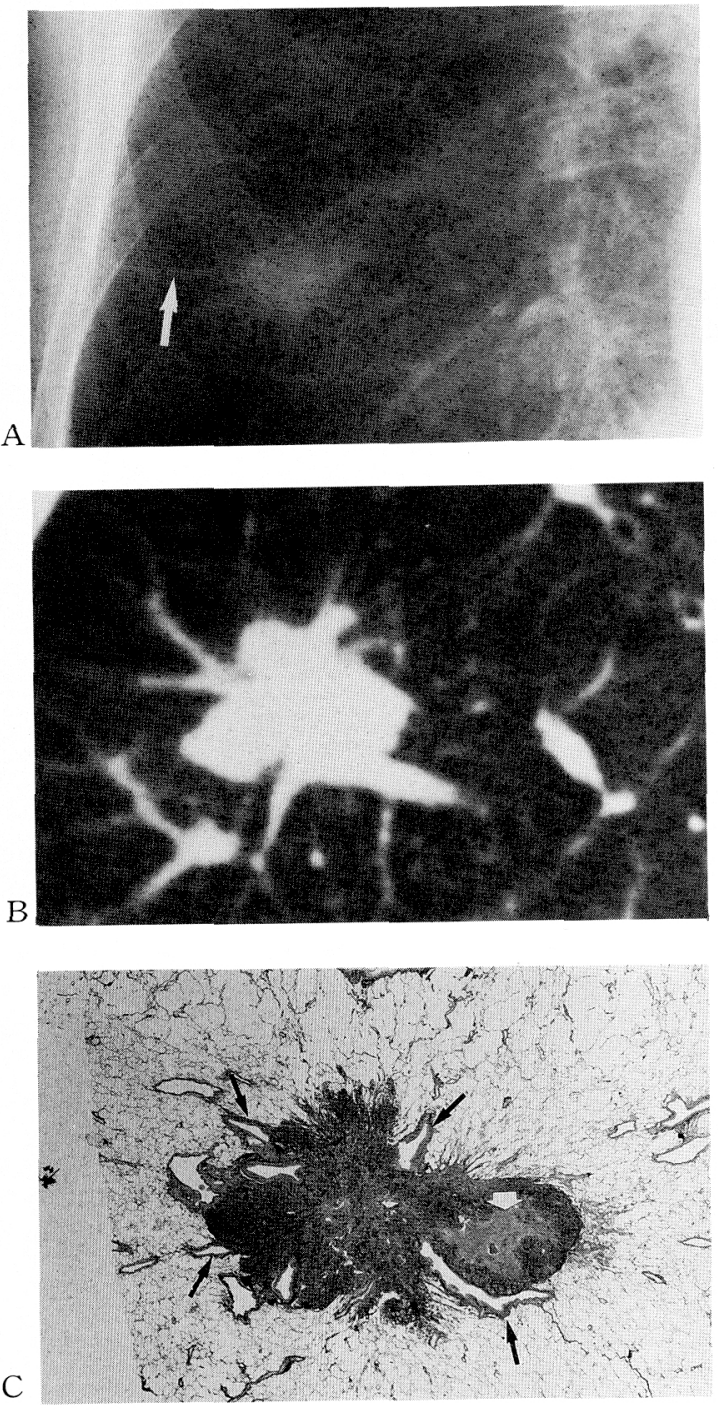

Fig. 2. A 66-year-old man (Case 1) with a tubular adenocarcinoma of the right lower lobe and a papillary adenocarcinoma of the right upper lobe simultaneously. (A) Anteroposterior tomogram shows irregular shadow (arrow) with convergence of peripheral vessels (arrowheads). (B) Thin-section CT shows a lobulated nodule with pleural indentation (arrows) with convergence of peripheral vessels (arrowheads). (C) Correlating pathologic specimen shows it to be a well-differentiated papillary adenocarcinoma with central fibrosis. In the peripheral area, tumor cells extend along alveolar septa randomly, resulting in poorly defined advancing margins. The linear shadow is shown to represent thickened connective tissue septa (arrow) extending toward the pleural surface.

A

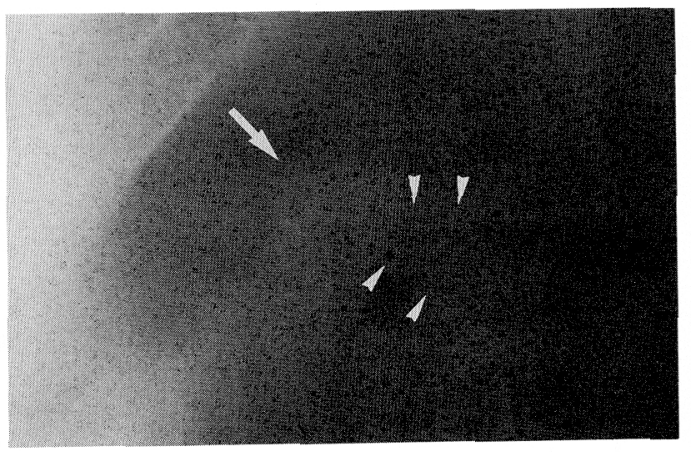

B
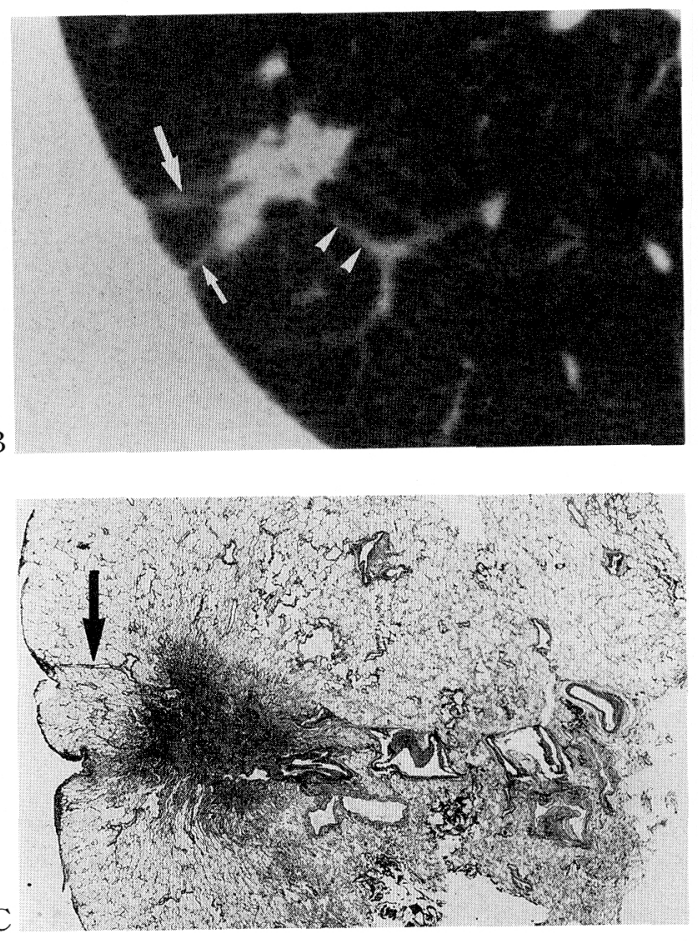
Fig. 3. A 45 year-old man (Case 5) with a papillary adenocarcinoma of the right lower lobe. (A) CT (10 mm) shows an ill-defined nodular shadow with convergence of peripheral vessels (arrowheads). (B) Thin-section CT shows a lobulated nodule containing multiple small cavities (arrows). (C) Correlating pathologic specimen shows it to be well-differentiated papillary adenocarcinoma with diffuse interstitial fibrosis. Small bronchioles within the tumor show microcystic dilatation. Tumor cells extend along alveolar septa, resulting in poorly defined advancing margins and fluffy roentgen density.

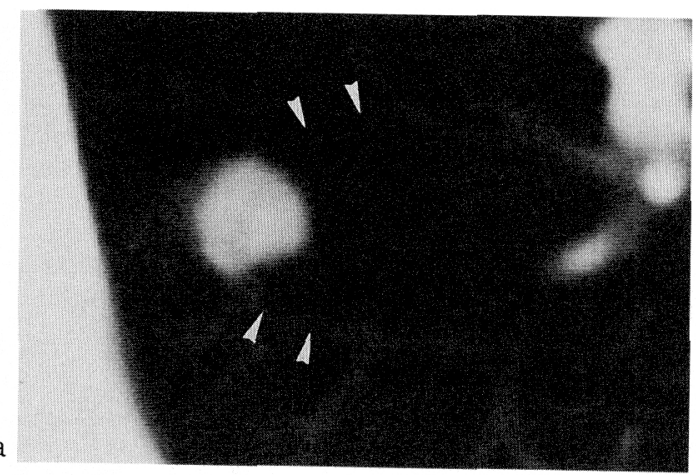

つき検討した (Table 2). X線写真の解析は放 射線診断医 3 名が独立して形態学的特徵を記述 し, 読影者間で解釈の一致した所見を採用した。

\section{結 果}

I）各 X 線診断の小型肺癌に対する診断能の比 較検討 (Table 2)

1)胸部単純写真

胸部単純写真では腫瘤影が小さくて陰影の濃 度が淡く辺縁が不鮮明なために, 存在診断のみ で質的診断は困難であった。しかしながら，症 例 4 では腫瘤影が小さくても単純写真のみで辺 縁の凹凸，胸膜の陥入像が明瞭に認められた (Fig. $1-\mathrm{A})$.

2) X線断層写真

$\mathrm{X}$ 線断層写真では前後の血管・気管支影の重 なりが除かれるために, 腫瘤影の辺縁の性状が 胸部単純写真より明瞭となり, 周辺の血管・気 管支影の集束像も比較的良好に描出された。し かしながら，肺野末梢部の胸壁近くの腫瘤に対 する胸膜の陥入像はボケ像や流れ像のために描 出が困難で亦った(Fig. 2-A)。

3)ルーチンCT $(10 \mathrm{~mm})$

従来より施行されている胸部のルーチン CT 検査では, Volume averaging effectのために空 間分解能が悪く腫瘤影の辺縁が不明瞭であった。
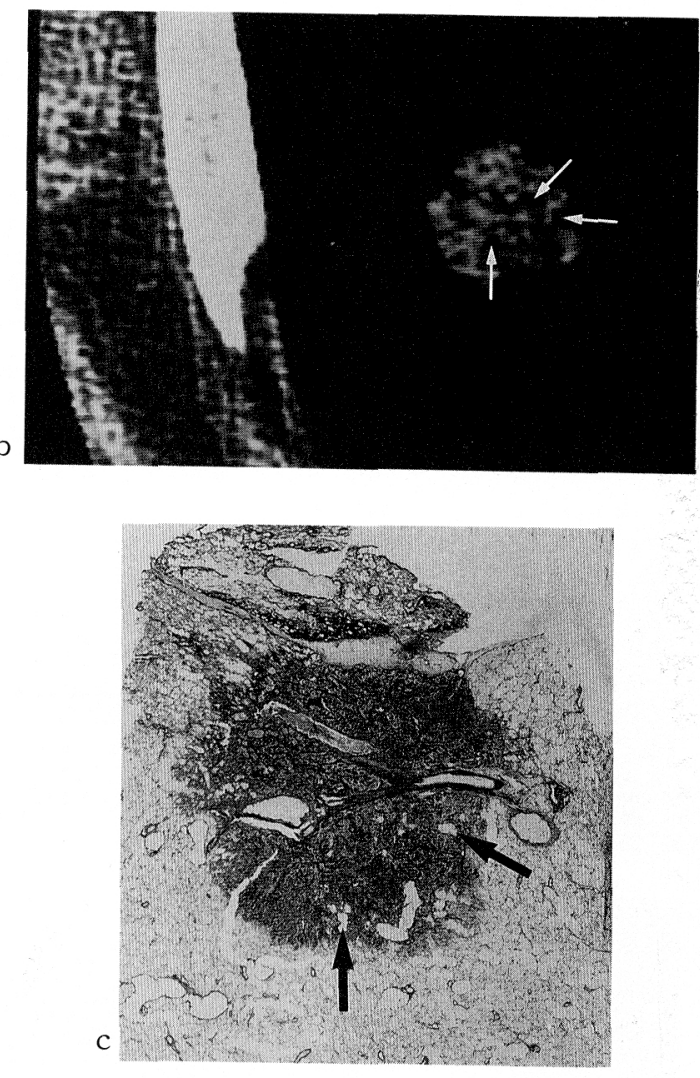

しかしながら，周囲血管影の集束性変化や胸膜 陥入像の描出能はX線断層写真と殆ど同じであ った (Fig. 3-A).

4) Thin-section $C T(1.5 \mathrm{~mm})$

Thin-section CTでは全症例に辺縁の凹凸と 周囲の血管・気管支の集束性変化が良好に描出 己れ, 棘状突起, 胸膜の陥入像も高頻度に認め られた。また良性結節の診断に有用とされてい る石灰化や脂肪は全例に認められなかった。今 回検討した症例が扁平上皮癌, 大細胞癌では各 1 例と少ないために病理組織別の特徵を腺癌 (乳頭腺癌) と比較検討し得ないが, 乳頭腺癌で は 5 例中 4 例に腫瘍内の小空洞を， 2 例に腫瘍 内の中心部之辺縁部の濃度差を描出可能であっ 
Table 3. Thin-section CT findings.

\begin{tabular}{lcccc}
\hline Thin-section CT & Adenoca. & Squamous cell & Large-cell & Total \\
\hline Notch & $5 / 5$ & 1 & 1 & $7 / 7$ \\
Spiculation & $5 / 5$ & 1 & 0 & $6 / 7$ \\
Pleural retraction & $4 / 5$ & 1 & 0 & $5 / 7$ \\
Convergence of peripheral & $5 / 5$ & 1 & 1 & $7 / 7$ \\
bronchi and vessels & & & & \\
Small cavity & $4 / 5$ & 0 & 0 & $4 / 7$ \\
Heterogeneous density & $2 / 5$ & 0 & 0 & $2 / 7$ \\
\hline
\end{tabular}

Fig. 4. A 45 year-old female (Case 2) with a papillary adenocarcinoma of the right upper lobe. (A) Localized view of the right upper lung from posterioanterior radiograph shows fluffy and lobulated shadow of increased density (arrow). (B) Thin-section CT shows a lobulated nodule with a peripheral fluffy zone containing an air-bronchogram (arrow) and small cavities (arrowheads). (C) Correlating pathologic specimen shows it to be well-differentiated papillary adenocarcinoma with central fibrosis. In the peripheral area, tumor cells extend along the alveolar septa. In the 1-2 o'clock sector, the advancing margin is limited by an interlobular septum (arrow).
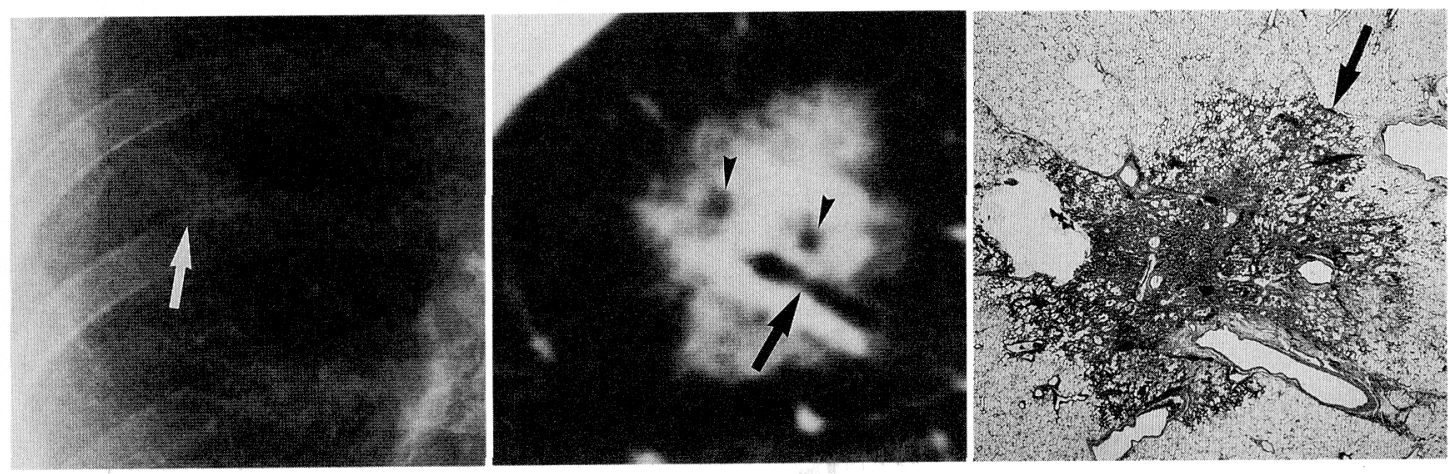

た (Table 3, Fig. 3-B, Fig. 4-B).

II) Thin-section CTと切除肺癌ルーペ像との対 上t

Thin-section CTにより描出された所見をス キャン面に対応させ水平にスライスした摘出肺 の病理像と比較検討した。微小癌であっても， thin-section CTは摘出肺のルーぺ像と酷似し, 肺癌に特徵的な辺縁の凹凸, 棘状突起, 胸膜の 陷入像や周囲血管の集束性変化の描出が可能で あった(Case 1, Fig. 2). 腫瘤影内の小筀洞が thin-section CTにより描出可能であり, これは 病理像では腫瘍内で拡張した細気管支に相当し た(Case 5, Fig. 3). また癌の中心の線維化部 分と辺縁部の肺胞壁に沿い浸潤性に増殖する部 分が腫瘍濃度差としてthin-section CTにより 描出された(Case 2, Fig. 4).

\section{考案}

肺野部肺癌は亜区域支から末梢側の気管支肺 胞系に発生し, 孤立性腫瘤陰影もしくは限局性 浸潤陰影を呈する ${ }^{5)}$. 腫瘍の大きさが $2 \mathrm{~cm}$ 以上 に発育すると, 胸部単純・断層像で辺縁の山凸, 棘状突起, 胸膜の陥入, 周囲血管影の集束など の肺癌に特徵的な所見を呈してくる.しかしな がら，ごく早期のものは腫瘍も小さく，組織に よっては含気性の構築を残しているために淡い 限局性浸潤陰影を呈するのみの症例もあり従来 の画像診断法では肺癌に特徵的なX線所見を描 
出することは困難であった ${ }^{6,7)}$.

CTは従来のX線学的手法に比して濃度·空間 分解能が良いが, 肺野部小型肺癌では対象とす る病変が小さいために従来の厚さ $10 \mathrm{~mm}$ のマキ ヤンでは辺縁の性状の描出が断層写真に劣って いた ${ }^{8)}$.

肺野のCT像の分析にはスライスの厚みが重 要な因子であり,とくに肺はその含気のためCT 值が非常に低くvolume averaging effectによ り肺内の正常微細構築像の描出が困難であった. スライスの厚みが薄いthin-section CTは従来 のX線学的手法に比して, 濃度・空間分解能が 良く病巣周囲の正常微細構築像の描出に優れて いるため腫瘤影の辺縁の性状や周囲の血管 - 気 管支の集束性変化, 胸膜陥入像の描出に優れ, これらの病巣周辺構造との関係を分析すること により肺野部小型肺癌の進展様式を把握するこ

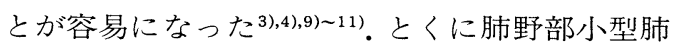
癌は上葉に好発し, X 線テレビ透視下の病巣へ のアプローチがやや困難であるが，上肺野の thin-section CTでは心拍動や呼吸によるアー チファクトが少ないため良好な画質を得ること ができた。

病理像で腫瘍内の拡張した細気管支が，断層 写真では濃度が不均一な腫瘤影として描出され たがthin-section CTでは腫瘍内の小空洞とし て描出された(Case 5, Fig. 3).ささら拡大scale (window width : 1500, level : $-600 \mathrm{H}$ ) を用い ることにより癌の中心の線維化部分と辺縁部の 肺胞壁に沿い浸潤性に増殖する部分が腫瘍濃度 差として描出可能であり, 腫瘍の進展様式より 組織型および分化度の推定が可能になると思わ
れる(Case 2, Fig. 4) 9),10).

従来より肺結節の石灰化は良性の所見とされ， さらにCT值により定量的に検出することは 良・悪性の鑑別に有用とされてきたが, 否定的

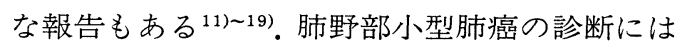
CT值による診断のみでは鑑別が困難な場合が 多く，形態的特徵も合わせて解析することによ り診断能を向上させることが必要と考えられ $3^{11), 16), 17}$. 肺野部小型肺癌のthin-section CT像 は切除肺の病理像 (ルーぺ像) と良く対応し, 肺 結節性病変の良·悪性の鑑別に際しCT值による 石灰化巣や脂肪の検出に加之て, 形態的特徵を 解析することにより診断能が向上することを示 唆している3 ${ }^{3), 4), 11}$. 従って, 確定診断が得られな い肺野部小型肺癌に対し病理像に迫る画像診断 法とし積極的に施行すべき検査であると考える.

\section{結 語}

肺野部小型肺癌 7 例につき, 従来の胸部単 純・断層写真と胸部CT $(10 \mathrm{~mm})$ 及びthin-section CT $(1.5 \mathrm{~mm})$ の診断成績を retrospectiveに 解析し比較検討した。また摘出肺を水平にスラ イスし, 病理像と thin-section CT像とを対比検 討した. Thin-section CTは肺癌の診断に有用 な所見の描出に優れており, 切除肺のルーぺ像 と対応していた. またthin-section CTにより初 めて腫瘍内の拡張した細気管支が小空洞として, 周辺部で癌細胞が肺胞壁に沿って浸潤する部分 が中心部に対して淡い濃度として描出すること ができ，良・悪性の鑑別のみならず組織型の類 推が可能であると考えられる。

\section{文 献}

1）厚生統計協会：国民衛生の動向一厚生の指標, $33(9): 53-61,1986$.

2）下里幸雄: 病理形態学的にみた小型肺癌の $\mathrm{X}$ 線像. 癌の臨床, 15:108-111, 1969.

3) Shin, M.S., Ho, K-J. : Computed tomographic evaluation of solitary pulmonary nodules in chest roentgenograms. J. Comput.

Assist. Tomogr. 6(5) : 947-954, 1982.

4）小林敏夫, 志田寿夫：肺小病変の画像診断, Coin lesionにおけるthin slice CTとconventional tomographyの比較検討. 日本医事新報 社, 東京, 252頁, 1985 .

5）成毛韶夫：肺末梢部早期がんの定義について. 厚生省がん研究報告集, 昭和55年度, 1980 . 
6）江口研二：腫瘍径 $1.5 \mathrm{~cm}$ 以下の切除腺癌の臨 床像. 第25回日本肺癌学会総会シンポ抄録集 『肺癌』, 1984.

7) 松本満臣, 中島信明, 高橋満弘, 他：肺癌の断 層撮影。放射線科, $2: 397-408,1983$.

8）森 雅樹, 森 拓二, 高橋保博, 他: 肺癌のCT 診断。放射線科， $2: 409-416 ， 1983$.

9) Heitzman, E.B. : The lung, Radiologic-pathologic correlations. C.V. Mosby Company, Missouri, P546, 1984.

10）鈴木 明：肺癌の発育発展様式と胸部 $\mathrm{X}$ 線像. 臨床医, 8:7-11, 1982.

11）尾山正孝：肺結節性病変のCT診断. 日本医放 会誌：46(9), 1094-1111, 1986.

12) Pare, J.A.P., Fraser, R.G. : Synopsis of diseases of the chest. W.B. Saunders Company, Philadelphia, P863, 1983.

13) Siegelman, S.S., Zerhouni, E.A., Leo, F.P. et al. : CT of the solitary pulmonary nodules. Am. J. Roentgenol., 135 : 1-13, 1980.
14) Godwin, J.D., Speckmann, J.M., Fram, E.K. et al. : Distinguishing benign from malignant pulmonary nodules by computed tomography. Radiology, 144 : 349-351, 1982.

15) Proto, A.V., Thomas, S.R. : Pulmonary nodules studied by computed tomography. Radiology, $156: 149-153,1985$.

16）中田 肇，仲山 親，寺嶋広美，他：肺結節性 病変におけるCT診断の再評価. 日本医放会 誌：46 (8), 1012-1016, 1986.

17) Siegelman, S.S., Khouri, N.F., Leo, F.P., et al. : Solitary pulmonary nodules : CT assessment. Radiology, 160 : 307-312, 1986.

18) Siegelman, S.S., Khouri, N.F., Scott, W.W. Jr., et al. : Pulmonary hamartoma : CT fingings. Radiology, $160: 313-317,1986$.

19) Zerhouni, E.A., Stitik, F.P., Siegelman, S.S., et al. : CT of the pulmonary nodule : a cooperative study. Radiology, $160: 319-327,1986$. 


\title{
Thin-Section CT of Peripheral Small Lung Cancer
}

\author{
Keiko Kuriyama ${ }^{1)}$, Ryuhei Tateishi'), Osamu Doi ${ }^{3)}$, Ken Kodama ${ }^{3)}$, \\ Takeshi Horai ${ }^{4)}$, Minoru Matsudd ${ }^{4)}$, Akiyoshi Kajita ${ }^{1)}$, \\ Yasusada Fujino ${ }^{1)}$, Junpei Ikezoe ${ }^{5)}$ and Shizuo Morimoto ${ }^{5)}$
}

1) Department of Diagnostic Radiology,

2) Department of Pathology,

3) Department of Surgery,

4) Department of Medicine,

The Center for Adult Diseases, Osaka

5) Department of Radiology, Osaka University Medical School

To demonstrate peripheral small lung cancer in detail, 7 patients were examined by CT (GE 9800scanner) using $1.5 \mathrm{~mm}$ scan. These patients had early lung cancer (5 papillary adenocarcinomas, 1 squamous-cell carcinoma, 1 large-cell carcinoma) seen on chest radiographs including one patient with double primary lung cancers. CT images were examined by extended scale (window width; $1500 \mathrm{H}$, level; $-600 \mathrm{H}$ ). All lesions were surgically resected and histopathological specimens were sliced transversely to correlate with thin-section CT images.

In thin-section CT images, findings suggesting malignancy, such as spiculation (86\%), lobulation $(100 \%)$, and retraction of the overlying visceral pleura $(71 \%)$, convergence of peripheral bronchi and vessels toward the tumor (100\%) were well demonstrated. CT images with extended scales could demonstrate that 2 papillary adenocarcinomas had peripheral fluffy zones. This finding was compatible with the observation of tumor cells spread on the alveolar walls in the pathologic specimen.

Our results suggest that thin-section CT may have a significant clinical role in diagnosing peripheral small lung cancer by demonstrating malignant favoring findings, especially when a histopathological specimen for making definitive daignosis of lung cancer is not available before operation. 